\title{
Evaluating the effects of vaccine rollout policies in European countries: A simulation study
}

\author{
P. Barmpounakis ${ }^{1} \quad$ N. Demiris ${ }^{1} \quad$ I. Kontoyiannis ${ }^{2} \quad$ G. Pavlakis ${ }^{3}$ \\ V. Sypsa ${ }^{4}$
}

\author{
${ }^{1}$ Athens University of Economics and Business, Greece \\ ${ }^{2}$ University of Cambridge, UK \\ ${ }^{3}$ National Cancer Institute, USA \\ ${ }^{4}$ National and Kapodistrian University of Athens, Greece
}

May 19, 2021

\begin{abstract}
The results of a simulation-based evaluation of several policies for vaccine rollout are reported. In the presence of limited vaccine supply, this policy choice is a pressing issue for several countries worldwide, and the adopted course of action will affect the extension or easing of non-pharmaceutical interventions in the next months. We employ a suitably generalised, age-structure, stochastic SEIR (Susceptible $\rightarrow$ Exposed $\rightarrow$ Infectious $\rightarrow$ Removed) epidemic model that can accommodate quantitative descriptions of the major effects resulting from distinct vaccination strategies. The different rates of social contacts among distinct agegroups are informed by a recent survey conducted in Greece. The results are summarised and evaluated in terms of the total number of deaths and infections as well as life years lost. The optimal strategy is found to be one based on fully vaccinating the elderly/at risk as quickly as possible, while extending the timeinterval between the two vaccine doses to 12 weeks for all individuals below 75 years old, in agreement with epidemic theory which suggests targeting a combination of susceptibility and infectivity. This policy, which is similar to the approaches adopted in the UK and in Canada, is found to be effective in reducing deaths and life years lost in the period while vaccination is still being carried out.
\end{abstract}

\section{Introduction}

Since December 2019, COVID-19 has presented a global threat to public health and to the worldwide economy, and it will likely continue to disrupt livelihoods until a high percentage of the population is vaccinated. High vaccination rates will be necessary to reach herd immunity in a short period of time. Standard theory (e.g. Andersson and Britton, 2000) suggests that a proportion approximately equal to $1-1 / R_{0}$ of the population will have to become immune (either through vaccination or previous infection) in order to effectively suppress disease transmission, where $R_{0}$ is the virus' basic reproduction number. The actual vaccination coverage required is likely to vary due to population heterogeneity, previous levels of spread of infection, and other local factors. In addition, the exact value of $R_{0}$ for SARS-CoV-2 under "normal" conditions remains quite uncertain since there has been very little disease spread without some mitigation effort due to nonpharmaceutical interventions. Therefore, constrained scenarios are likely to give a realistic estimate of the effect of distinct vaccination policies and this NOTE 
medRxiv preprint doi: https://doi.org/10.1101/2021.05.19.21257486; this version posted May 21,2021 . The copyright holder for this preprint (which was not certified by peer review) is the author/funder, who has granted medRxiv a license to display the preprint in perpetuity. It is made available under a CC-BY-ND 4.0 International license .

Assuming a vaccination coverage between $60 \%-80 \%$ of the population, 3.1-4.1 billion people worldwide will need to be vaccinated (Wang et al., 2020). With several seemingly highly efficacious vaccines available (efficacy estimated at $94.1 \%, 95 \%$ and $62 \%$ for Moderna, Pfizer-BioNTech and Oxford-AstraZeneca respectively) against COVID-19 disease (FDA, 2020; Polack et al., 2020; Voysey et al., 2021) it appears that a return to nearnormality for society and for the economy may soon be possible. Unfortunately, limited supply is currently an impediment to achieving high vaccination coverage rapidly (Bollyky, 2021).

In addition to social distancing (Lewnard et al., 2020) and mass testing (Taipale et al., 2021), the fair allocation of scarce medical interventions such as vaccines presents ethical challenges as there are different allocation principles - treating people equally, favouring the worst-off, maximising total benefits, and promoting and rewarding social usefulness - and no single principle can address all morally relevant considerations (Emanuel et al., 2020; Persad et al., 2009). Modelling studies broadly agree that, when vaccine supply is limited, prioritising the elderly is a necessary strategy to reduce COVID-19 mortality, whereas the prioritisation of younger individuals would have an impact on reducing transmission (Bubar et al., 2021; Matrajt et al., 2020). This is in agreement with epidemic theory (e.g. Andersson and Britton, 2000) which suggests that the focus for disease control should be based on a combination of targeting susceptibility and infectivity. Therefore, assuming very scarce resources, it makes sense to focus upon the most vulnerable individuals in the population. On the other extreme is the presence of nearly unlimited vaccine supply, whence aiming for achieving herd immunity is straightforward. In this work we focus on the intermediate problem which many European countries are currently facing, and prioritisation of vaccines is of the essence.

Due to supply constraints, it was decided in the UK to delay the administration of the second dose based on the rationale that SARS-CoV-2 vaccines offer considerable protection after the first dose and that more people could benefit. Although this approach seems appealing, the impact of delaying the second dose is not straightforward as it depends on several parameters such as the efficacy of the first dose in time, the levels of transmission in the population, vaccination rollout, and the vaccine profile (reduction in symptoms or in symptoms and infection) (Matrajt et al., 2021; Paltiel et al., 2021a, 2021b). Country-specific information on the agedistribution of the population and social mixing patterns are also necessary to obtain realistic estimates.

The main contribution of this work is the evaluation of different vaccination strategies and their potential benefits in Greece, a typical country of the EU area in terms of vaccine availability and administration. The current strategy (strategy I) is to give the second vaccine dose three weeks after the first for the Pfizer vaccine, which currently consists of the largest portion of the available vaccines in the EU. We consider an alternative policy (strategy II) where, after the vaccination of medical personnel and those over 75, a portion of the available vaccines is distributed with a three-month time interval between the two doses. This aims for faster partial coverage of economically active individuals, therefore offering indirect protection to 
medRxiv preprint doi: https://doi.org/10.1101/2021.05.19.21257486; this version posted May 21,2021 . The copyright holder for this preprint (which was not certified by peer review) is the author/funder, who has granted medRxiv a license to display the preprint in perpetuity.

It is made available under a CC-BY-ND 4.0 International license .

a larger proportion of the population and ultimately for potentially reducing the pandemic cost to public health and the society. This is implicitly informed by aiming for a combined effect of reducing susceptibility and infectivity in the population. Different scenarios of vaccine availability and transmission rates are considered, as well as different scenarios for the acquired immunity after the first dose for strategy II. We assess our results through simulation of an age-structured stochastic SEIR (Susceptible $\rightarrow$ Exposed $\rightarrow$ Infectious $\rightarrow$ Removed) epidemic model, suitably modified to account for the number of vaccinated individuals with different protocols.

\section{The multitype S(V)EIR model and simulation description}

The model used for the simulations for the different vaccination strategies is an age-structured stochastic SEIR model that accounts for different vaccinated populations, termed S(V)EIR henceforth. A schematic representation of the model is given in Figure 1 . In order to evaluate the effects of different vaccination strategies to the Greek population, this model also accounts for the age composition of the population, the social mixing rates of different age groups, the intention to get vaccinated, as well as the different risk of death of each age group. The code for simulating the model is made freely available at:

https://github.com/pbarmpounakis/Evaluating-the-effects-of-vaccinerollout-policies-in-European-countries-A-simulation-study.

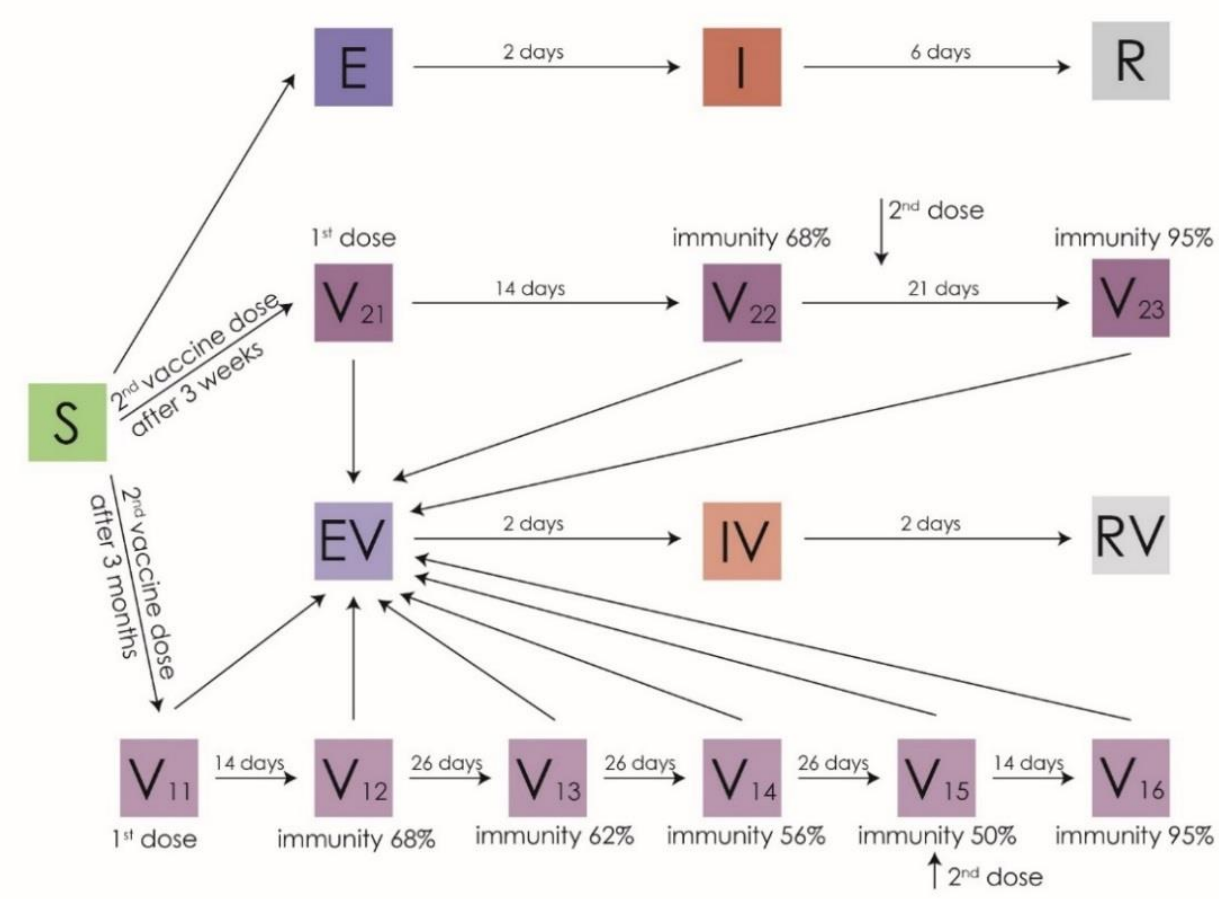

Figure 1: Schematic representation of the S(V)EIR epidemic model for the baseline scenario regarding immunity waning.

A detailed description of the model follows, while a table summarising the quantitative assumptions made is given in Appendix $B$. 
medRxiv preprint doi: https://doi.org/10.1101/2021.05.19.21257486; this version posted May 21,2021 . The copyright holder for this preprint (which was not certified by peer review) is the author/funder, who has granted medRxiv a license to display the preprint in perpetuity. It is made available under a CC-BY-ND 4.0 International license .

\section{States and vaccination effect assumptions}

Two groups are considered for the vaccinated people representing the two distinct vaccination categories. In vaccination group 1 , individuals receive the $2^{\text {nd }}$ dose of the vaccine after 3 months while in vaccination group 2 it is given after 3 weeks. In both vaccination groups, individuals who received the $1^{\text {st }}$ dose of the vaccine move to states V11 and V21 respectively and remain fully susceptible. Two weeks after the $1^{\text {st }}$ dose individuals from both vaccination groups move to the second stage (V12, V22 respectively), whence immunity jumps to $68 \%$. Individuals from vaccination group 2 remain at $\mathrm{V} 22$ for another 7 days when they take their $2^{\text {nd }}$ dose and move to state 3 (V23) with their immunity jumping at $95 \%$. Individuals from vaccination group 1 take their second dose 78 days after entering V12 and then move to state V15 with their immunity dropping linearly (from $68 \%$ to $50 \%$ ). They move to V16 14 days later when their immunity jumps to $95 \%$.

\section{Transmission model assumptions}

New infections from each state $s$ and age group $i$ follow a Binomial distribution with size given by the number of people in state $s$ and age group $i$, and infection probability $\left(1-\right.$ immunity $\left._{i}\right) * e^{\sum_{j=1}^{n-g r o u p s}\left(\lambda_{i j} * I_{j} / N_{j}\right)}$, where immunity $_{s}$ is the level of immunity at stage $s_{1} I_{j}$ is the number of infectious individuals at age group $j, N_{j}$ is the total number of individuals at age group $j, \lambda_{i j}$ is the $i, j$ entry in the transmission matrix $\lambda$, and $n$ groups is the total number of different age groups. Following infection, individuals of age group $i$ follow the Exposed $\left(E_{i}\right) \rightarrow$ Infectious $\left(I_{i}\right) \rightarrow$ Removed $\left(R_{i}\right)$ path with a constant exposure time of 2 days and constant infectious period set at 6 days for non-vaccinated individuals and 2 or 3 days for vaccinated ones, depending upon the scenario of immunity waning. The total number of deaths is computed by multiplying the number in $\mathrm{R}_{\mathrm{i}}$ with the infection fatality ratio (IFR) of each age group for the unvaccinated individuals and with [IFR x 5\%] for those vaccinated (Haas et al., 2021).

\section{Different scenarios for $\boldsymbol{R}_{\mathbf{0}}$ and immunity}

Transmission levels corresponding to $R_{0}=1.2$ and $R_{0}=1.4$ are considered along with various levels of immunity at each stage of vaccination for group 1. We ran 1000 simulations for each scenario and computed the median as well as $90 \%$ equal-tailed uncertainty intervals.

Worst Case Scenario: It is assumed that, during the time interval of 3 months between the first and second dose (strategy II), the acquired immunity drops linearly to 34\% (Supplementary Figure 1, Appendix A). The effective infectious period of those vaccinated is reduced by $50 \%$ to 3 days.

Baseline Scenario: Here it is assumed that during the 3 months between the two doses (strategy II) the acquired immunity drops linearly to $50 \%$ and the infectious period of those vaccinated is set at 2 days (Figure 1 ).

Optimistic Scenario: In this case a constant immunity of $68 \%$ is assumed for the interval between the first and the second dose and the infectious period lasts 2 days (Suppl. Figure 2, Appendix A). 
medRxiv preprint doi: https://doi.org/10.1101/2021.05.19.21257486; this version posted May 21 , 2021. The copyright holder for this preprint (which was not certified by peer review) is the author/funder, who has granted medRxiv a license to display the preprint in perpetuity.

It is made available under a CC-BY-ND 4.0 International license .

\section{Fraction of vaccines given to general population}

Different percentages are considered for the proportion of the available vaccines distributed under strategy II. These are set to $0 \%$ (strategy I), $20 \%, 50 \%$ and $100 \%$ (strategy II), and the resulting number of deaths and years lost are calculated for each of these cases.

\section{Vaccine Availability}

Two levels of vaccine availability are used, with a baseline level and a limited level with reduced number of vaccines; see Appendix B.

\section{Results}

Our main finding is that the optimal strategy in terms of the reduction in deaths and number of years lost, is the one that where all available vaccine doses are given under strategy II, using a time interval of three months between the two doses.

\begin{tabular}{|l|l|}
\hline strategy II vs. strategy I & $\begin{array}{l}\text { Total \% reduction under strategy I } \\
\text { during January-December } \mathbf{2 0 2 1}\end{array}$ \\
\hline Gain in number of deaths & $579(9.04 \%)$ \\
\hline Gain in years of life & $14802(10.65 \%)$ \\
\hline
\end{tabular}

Table 1: Comparison of strategy I and strategy II (at $100 \%$ doses given) for 2021 with $R_{0}=1.2$, under the baseline immunity assumption and standard vaccine availability. "Gain" refers to the number of fewer deaths and life years lost under strategy II (extended interval between doses).

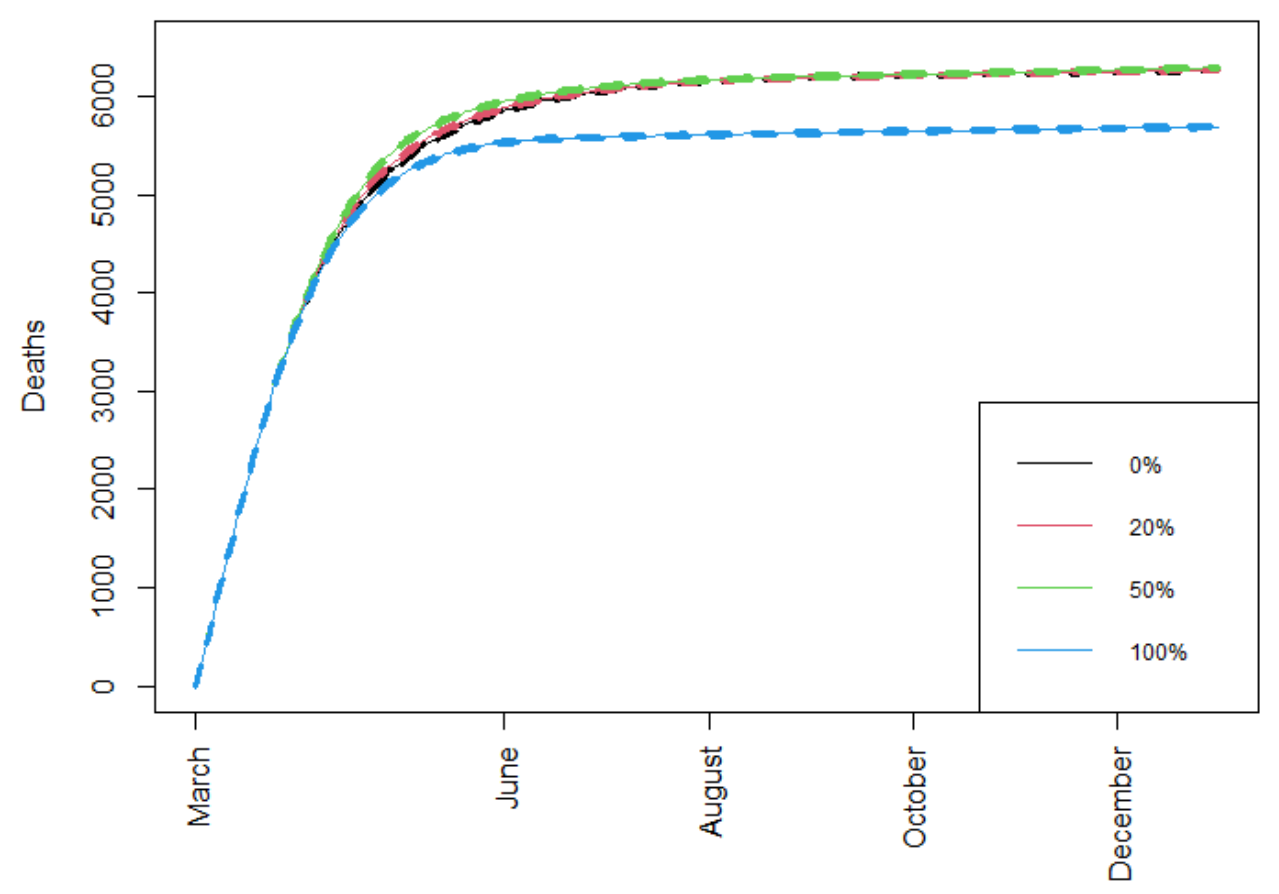

Figure 2: Cumulative number of deaths over time when different percentages of doses are allocated under strategy II, with $R_{0}=1.2$, immunity drop between the two vaccine doses is at the Baseline scenario, and with standard vaccine availability. 
medRxiv preprint doi: https://doi.org/10.1101/2021.05.19.21257486; this version posted May 21 , 2021. The copyright holder for this preprint (which was not certified by peer review) is the author/funder, who has granted medRxiv a license to display the preprint in perpetuity.

It is made available under a CC-BY-ND 4.0 International license .

The results vary, depending upon the adopted scenarios regarding immunity waning and the value of $R_{0}$, but they are robust in the sense that, in all cases, the optimal strategy, is found to be the one that allocates $100 \%$ of the available doses under strategy II.

Next, we present plots of the results for the baseline immunity waning scenario with $R_{0}=1.2$, and with standard vaccine availability (Figures 3-5); detailed tables are given in Appendix $C$ and several additional results from the optimistic and worst-case scenarios are summarised in a web supplement at:

https://github.com/pbarmpounakis/Evaluating-the-effects-of-vaccinerollout-policies-in-European-countries-A-simulation-study

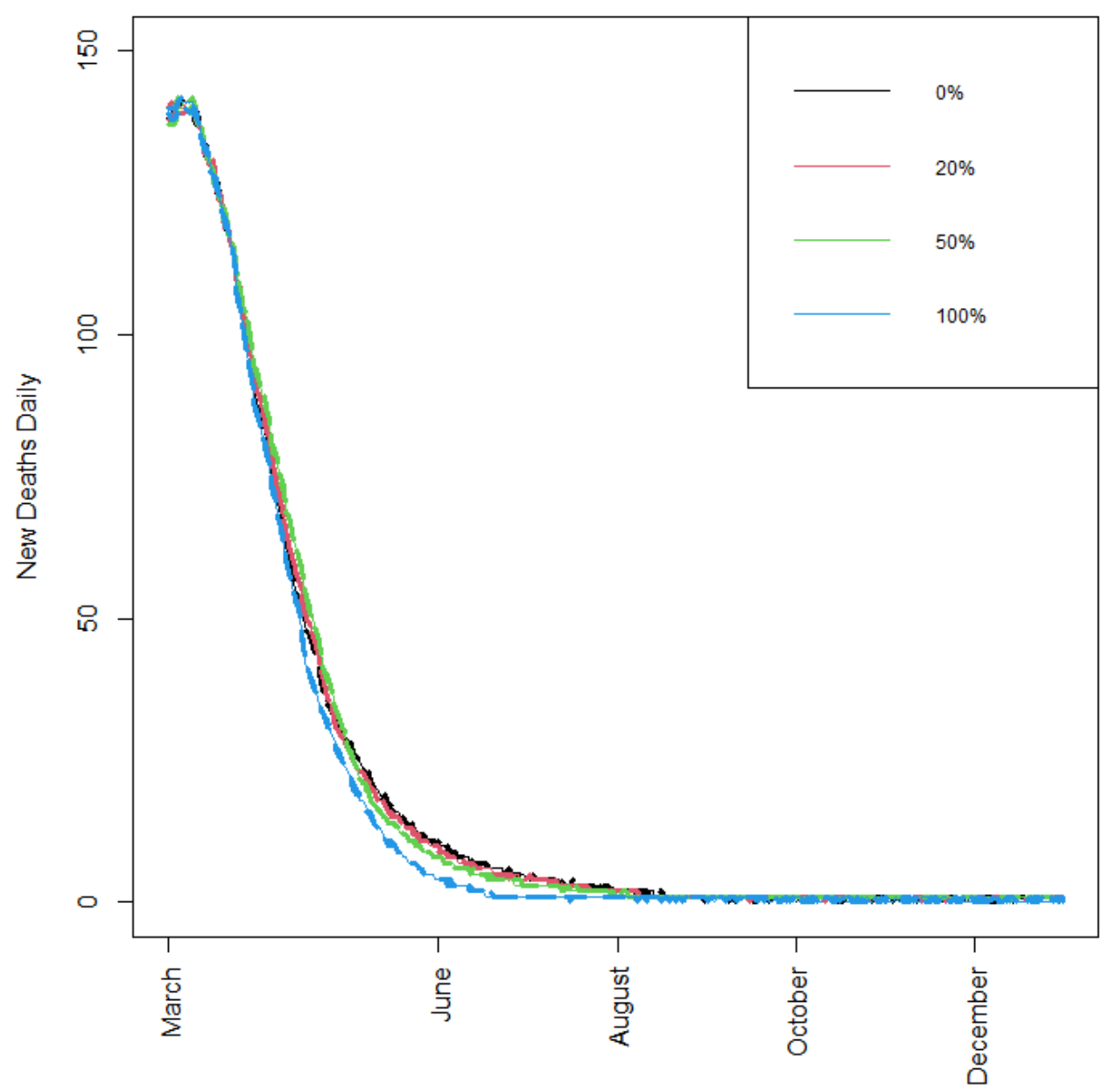

Figure 3: Number of new daily deaths, when different percentages of doses are allocated under strategy II, $R_{0}=1.2$, immunity drop is at the Baseline scenario, and with standard vaccine availability. [A zoomed-in version of this figure is available in the supplement, offering higher resolution locally.] 
medRxiv preprint doi: https://doi.org/10.1101/2021.05.19.21257486; this version posted May 21, 2021. The copyright holder for this preprint (which was not certified by peer review) is the author/funder, who has granted medRxiv a license to display the preprint in perpetuity.

It is made available under a CC-BY-ND 4.0 International license .

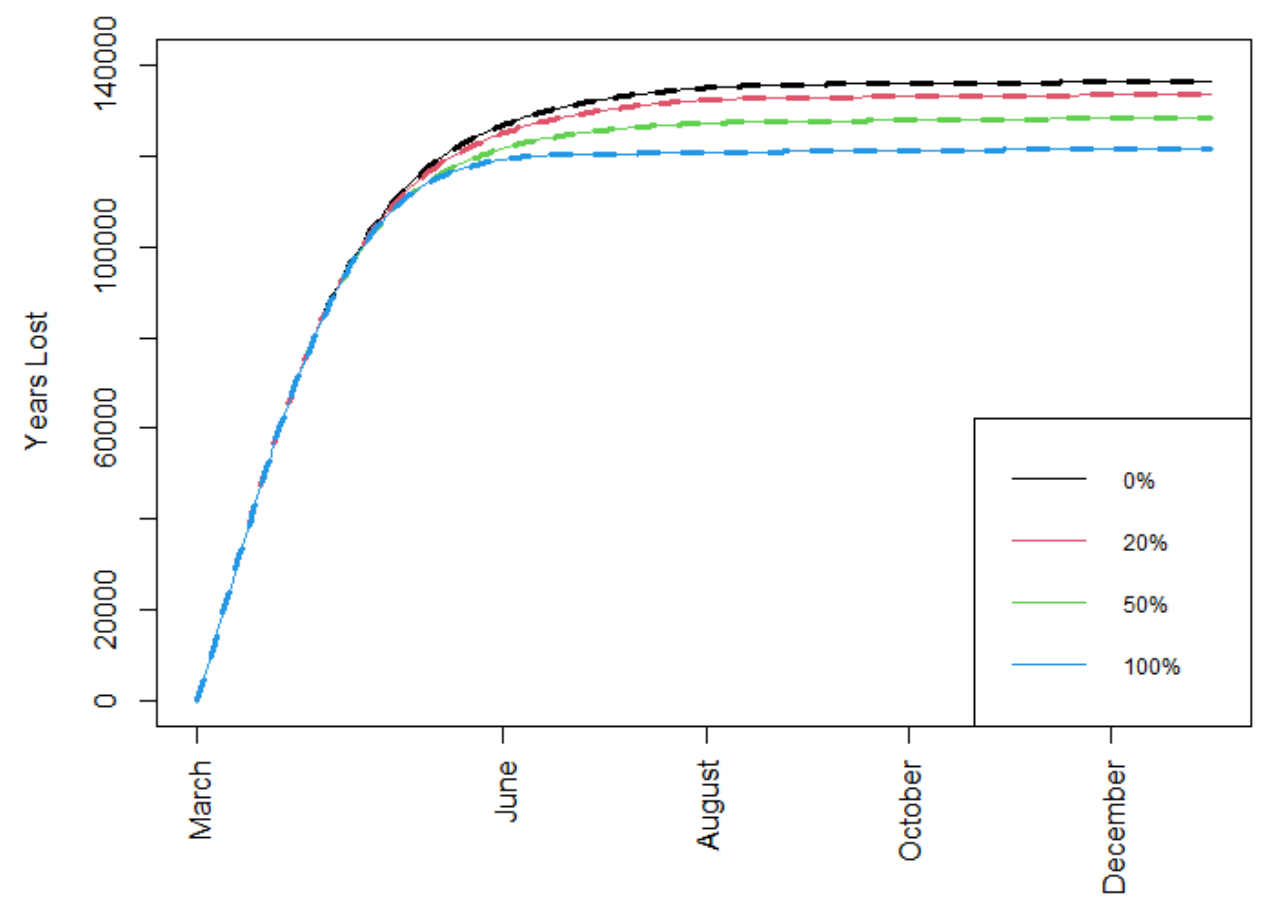

Figure 4: Total number of years of life lost when different percentages of doses are allocated under strategy II, when $R_{0}=1.2$, immunity drop is at the Baseline scenario, and with standard vaccine availability.

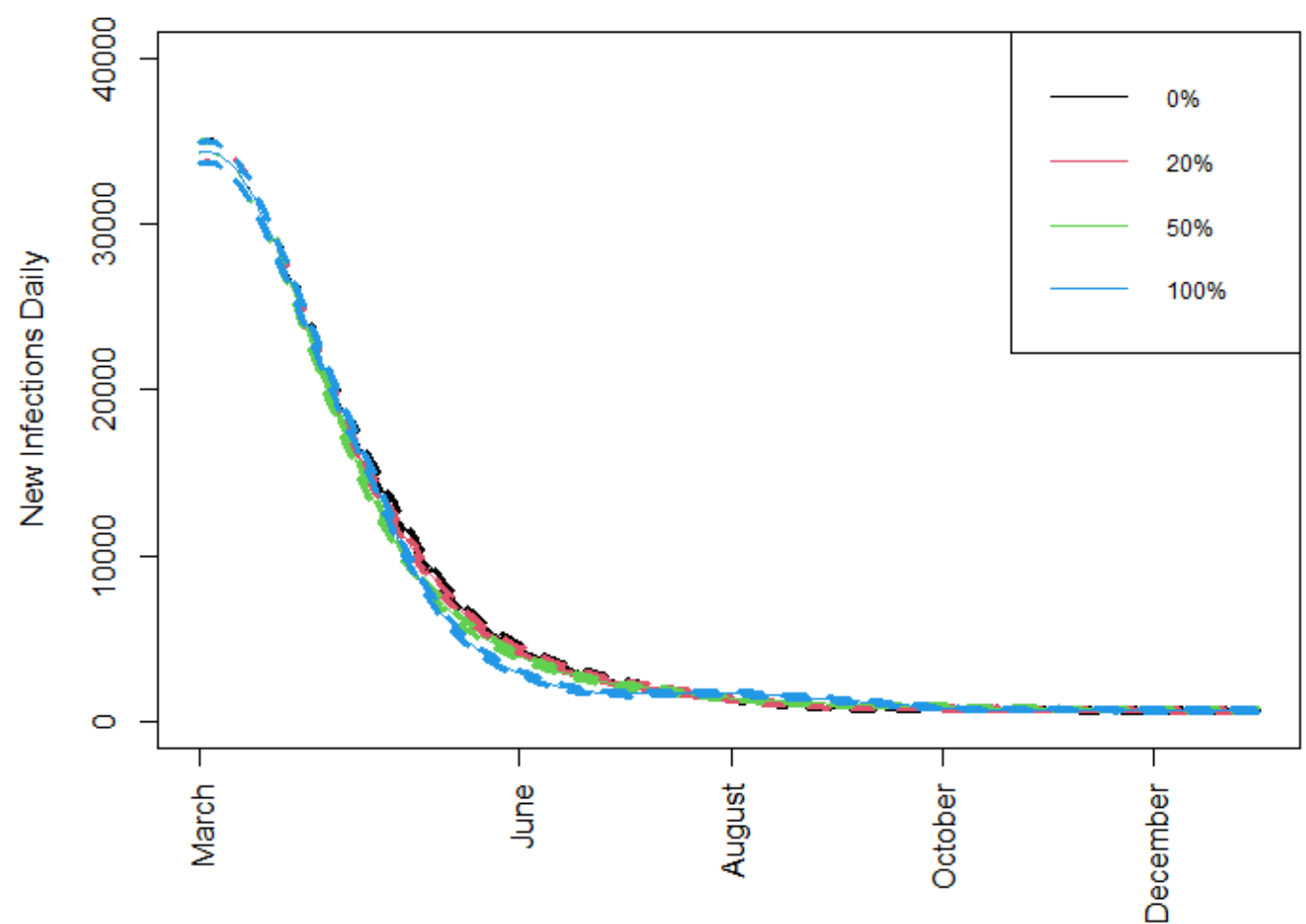

Figure 5: New daily infections when different percentages of doses are allocated under strategy II, when $R_{0}=1.2$, immunity drop is at the Baseline scenario, and with standard vaccine availability. 
medRxiv preprint doi: https://doi.org/10.1101/2021.05.19.21257486; this version posted May 21 , 2021. The copyright holder for this preprint (which was not certified by peer review) is the author/funder, who has granted medRxiv a license to display the preprint in perpetuity. It is made available under a CC-BY-ND 4.0 International license .

\section{Discussion}

After vaccination of medical personnel, individuals with high risk of fatal outcome from COVID-19, and people aged over 75 years old with a time interval of 3-4 weeks between the two vaccine doses, the strategy of vaccinating the rest of the population with an interval of three months between the two doses can result in a significantly reduced number of deaths and years of life lost in the Greek population. When only $20 \%$ or $50 \%$ of the available vaccines are distributed using strategy II, the results are not significantly different to strategy I in terms of deaths, although they do provide an improvement in the number of life years saved. In conclusion, rolling out $100 \%$ of the available vaccines using the delayed second dose strategy appears to be the most effective option.

In the absence of detailed social contact data between different groups, we accounted for age groups as a surrogate for population composition, and we used the contact rate data between different age-groups from the recent survey (Sypsa et al., 2021). Therefore, the results reported here offer a conservative assessment since no attempt is made to prioritize individuals with many contacts such as mass transit employees, those working in the hospitality industry, super-markets and so on. Consequently, in practice, the benefits are expected to be even greater if a more targeted approach is adopted.

We used a multitype, age-structured, stochastic epidemic model with constant transmission rate and constant exposed and infectious periods. This approach has some limitations which are not expected to materially affect the results. First, in our model, we assumed that vaccine efficacy was mediated by a reduction in infections and not just in clinical disease. Recent modelling studies suggests that, if vaccines reduce symptomatic infection only, then the optimal protection for minimising deaths is prioritise older individuals (e.g., Matrajt et al., 2021). Our assumption seems realistic as recent data suggest that COVID-19 vaccines are effective in the prevention of infection (Amit et al., 2021; Thompson et al., 2021). Second, we assessed two scenarios for viral transmission rates $\left(R_{0}=1.2\right.$ and $\left.R_{0}=1.4\right)$. For higher transmission levels, a recent study similarly found that vaccinating high-risk groups first constituted the optimal use of available vaccines (Matrajt et al., 2021). On the other hand, moderate transmission levels are a more realistic scenario as most counties continue to implement social distancing measures during vaccination. Alternative scenarios may be considered for the transmission rate, but the overall outcomes are not expected to be substantially influenced as the current assumptions regarding $R_{0}$ may be thought of as an "average" version of a time-varying rate. In addition, it is known (e.g. Andersson and Britton, 2000) that the final size of a stochastic epidemic is invariant to the presence of an exposed period and to different distributional assumptions on the infectious period duration. Hence, these assumptions will not alter the conclusions of this work. Other recent relevant results supporting our assumptions include (Tuite et al., 2021; Vasiliou et al., 2021).

Although we have chosen to primarily emphasize the results of the proposed approach in terms of quantities of interest in public health, additional gains are to be expected in terms of social and economic aspects of public life by offering faster vaccine coverage to the economically active population. An 
medRxiv preprint doi: https://doi.org/10.1101/2021.05.19.21257486; this version posted May 21,2021 . The copyright holder for this preprint (which was not certified by peer review) is the author/funder, who has granted medRxiv a license to display the preprint in perpetuity.

It is made available under a CC-BY-ND 4.0 International license .

empirical application of the proposed approach is effectively followed in the United Kingdom, and the outcome seems to be a significantly faster overall reduction in SARS-CoV-2 circulation.

Overall, our results clearly indicate that, in the presence of a limited vaccine supply, distributing all available doses with a 3-month intermediate time interval could offer important advantages in terms of public health as well as to the wider society and the economy.

\section{References}

Amit, S., Regev-Yochay, G., Afek, A., Kreiss, Y., Leshem, E. (2021). Early rate reductions of SARS-CoV-2 infection and COVID-19 in BNT162b2 vaccine recipients. The Lancet, 397 (10277), 875-877.

Andersson, H., \& Britton, T. (2000). Stochastic Epidemic Models and Their Statistical Analysis. Lecture Notes in Statistics, vol 151, Springer, New York, NY.

Baden, L. R. et al. (2021). Efficacy and safety of the mRNA-1273 SARSCoV-2 vaccine. New England. Journal of Medicine, 384:403-416.

Bi, Q. et al. (2020). Epidemiology and transmission of COVID-19 in 391 cases and 1286 of their close contacts in Shenzhen, China: a retrospective cohort study. The Lancet Infectious Diseases, 20(8): 911-919.

Bollyky, T.J. (2021). U.S. COVID-19 Vaccination Challenges Go Beyond Supply. Annals of Internal Medicine. 174:558-559.

Cereda, D. et al. (2020). The early phase of the COVID-19 outbreak in Lombardy, Italy. arXiv e-prints; arXiv:2003.09320.

ELSTAT (2021), Greek Statistics Authority, https://www.statistics.gr/.

Emanuel, E.J., Persad, G., Upshur, R., Thome, B., Parker, M., Glickman, A., Zhang, C., Boyle, C., Smith, M., Phillips, J.P., (2020). Fair Allocation of Scarce Medical Resources in the Time of Covid-19. New England Journal of Medicine 382(21), 2049-2055.

FDA (2020). FDA Briefing Document, Moderna COVID-19 Vaccine, https://www.fda.gov/media/144434/download. Last accessed December 27, 2020.

Ganyani, T., Kremer, C., Chen, D., et al. (2020). Estimating the generation interval for coronavirus disease (COVID-19) based on symptom onset data. Eurosurveillance, 25(17):2000257.

Haas, J.E., Angulo, F.J., McLaughlin, J.M. et al. (2021). Impact and effectiveness of mRNA BNT162b2 vaccine against SARS-CoV-2 infections and COVID-19 cases, hospitalisations, and deaths following a nationwide vaccination campaign in Israel: an observational study using national surveillance. The Lancet, 397(10287): 1819-1829. 
medRxiv preprint doi: https://doi.org/10.1101/2021.05.19.21257486; this version posted May 21,2021 . The copyright holder for this preprint (which was not certified by peer review) is the author/funder, who has granted medRxiv a license to display the preprint in perpetuity. It is made available under a CC-BY-ND 4.0 International license .

He, X., Lau, E.H.Y., Wu, P. et al. (2020). Temporal dynamics in viral shedding and transmissibility of COVID-19. Nature Medicine 26(5):672675.

Koh, W.C. et al. (2020). What do we know about SARS-CoV-2 transmission? A systematic review and meta-analysis of the secondary attack rate and associated risk factors. PLOS ONE 15(10): e0240205.

Lauer, S.A., Grantz, K.H., Bi, Q. et al. (2020). The Incubation Period of Coronavirus Disease 2019 (COVID-19) From Publicly Reported Confirmed Cases: Estimation and Application. Annals of Internal Medicine, 172(9): 577-582.

Lavvezzo, E., Franchin, E., Ciavarella, C., Cuomo-Dannenburg, G., Barzon, L., Del Vecchio, C., et al. (2020). Suppression of a SARS-CoV-2 outbreak in the Italian municipality of Vo'. Nature. 584, 425-429.

Lewnard, J.A. et al., (2020). Scientific and ethical basis for social-distancing interventions against COVID-19. The Lancet Infectious Diseases, volume 20, issue 6, 631-633.

$\mathrm{Li}$, R., et al. (2020). Substantial undocumented infection facilitates the rapid dissemination of novel coronavirus (SARS-CoV2). Science, Vol. 368, Issue 6490, pp. 489-493.

Li Q., Guan X., Wu P., Wang X., Zhou L., Tong Y., et al. (2020). Early Transmission Dynamics in Wuhan, China, of Novel Coronavirus-Infected Pneumonia. New England Journal of Medicine, 382(13):1199-207.

Matrajt, L., Eaton, J., Leung, T., Brown, E.R. (2020). Vaccine optimization for COVID-19: Who to vaccinate first? Science Advances, 7(6).

Matrajt, L., Eaton, J., Leung, T., Dimitrov, D., Schiffer, J.T., Swan, D.A., Janes, H. (2021). Optimizing vaccine allocation for COVID-19 vaccines: potential role of single-dose vaccination. medRxiv, 2020.2012.2031. 20249099.

Paltiel, A. D., Schwartz, J. L., Zheng, A., Walensky, R. P. (2021a). Clinical Outcomes of a COVID-19 Vaccine: Implementation Over Efficacy. Health Affairs, 10-1377.

Paltiel, A.D., Zheng, A., Schwartz, J.L. (2021b). Speed Versus Efficacy: Quantifying Potential Tradeoffs in COVID-19 Vaccine Deployment. Annals of Internal Medicine, Volume 174, Issue 4, pp. 568-570.

Persad, G., Wertheimer, A., Emanuel, E.J., (2009). Principles for allocation of scarce medical interventions. The Lancet, 373(9661), 423-431.

Polack, F.P., et al. (2020). Safety and Efficacy of the BNT162b2 mRNA Covid-19 Vaccine. New England Journal of Medicine, 383(27), 2603-2615.

Skowronski D.M., De Serres G. (2020). Safety and efficacy of the BNT162b2 mRNA Covid-19 vaccine. [e-pub ahead of print]. New England Journal of Medicine. https://doi.org/10.1056/NEJMc2036242. Accessed February 15, 2021. 
medRxiv preprint doi: https://doi.org/10.1101/2021.05.19.21257486; this version posted May 21,2021 . The copyright holder for this preprint (which was not certified by peer review) is the author/funder, who has granted medRxiv a license to display the preprint in perpetuity. It is made available under a CC-BY-ND 4.0 International license .

Sypsa, V., et al. (2021). Effects of Social Distancing Measures during the First Epidemic Wave of Severe Acute Respiratory Syndrome Infection, Greece. Emerging Infectious Diseases. 27(2): 452-462.

Taipale, J., Kontoyiannis, I., Linnarsson, S. (2021). Population-scale testing can suppress the spread of infectious disease. arXiv:2104.06857 [qbio.PE].

Thompson, M.G. et al. (2021). Interim Estimates of Vaccine Effectiveness of BNT162b2 and mRNA-1273 COVID-19 Vaccines in Preventing SARS-CoV2 Infection Among Health Care Personnel, First Responders, and Other Essential and Frontline Workers - Eight U.S. Locations, December 2020March 2021. MMWR. Morbidity and Mortality Weekly Report 70(13), 495500.

Tuite, A.R, Zhu, L., Fisman, D.N., Salomon, J.A. (2021). Alternative dose allocation strategies to increase benefits from constrained COVID-19 vaccine supply. Annals of internal medicine, 174(4), 570-572.

CDC (2021). Covid-19 Pandemic and Planning Scenarios, US Centers for Disease Control and Prevention https://www.cdc.gov/coronavirus/2019ncov/hcp/planning-scenarios.html, March 19, 2021 udpate.

Vasileiou, E., et al. (2021). Effectiveness of first dose of COVID-19 vaccines against hospital admissions in Scotland: national prospective cohort study of 5.4 million people. The Lancet preprints, February 2021, available at SSRN: https://ssrn.com/abstract=3789264.

Voysey, M. et al. (2021). Safety and efficacy of the ChAdOx1 nCoV-19 vaccine (AZD1222) against SARS-CoV-2: an interim analysis of four randomised controlled trials in Brazil, South Africa, and the UK, The Lancet. 397:10269, 99-111.

Wang, W., et al. (2020). Global, regional, and national estimates of target population sizes for covid-19 vaccination: descriptive study. BMJ 2020;371:m4704. 
medRxiv preprint doi: https://doi.org/10.1101/2021.05.19.21257486; this version posted May 21, 2021. The copyright holder for this preprint (which was not certified by peer review) is the author/funder, who has granted medRxiv a license to display the preprint in perpetuity. It is made available under a CC-BY-ND 4.0 International license .

\section{Appendix A}

\subsection{Graphical presentation of different scenarios}

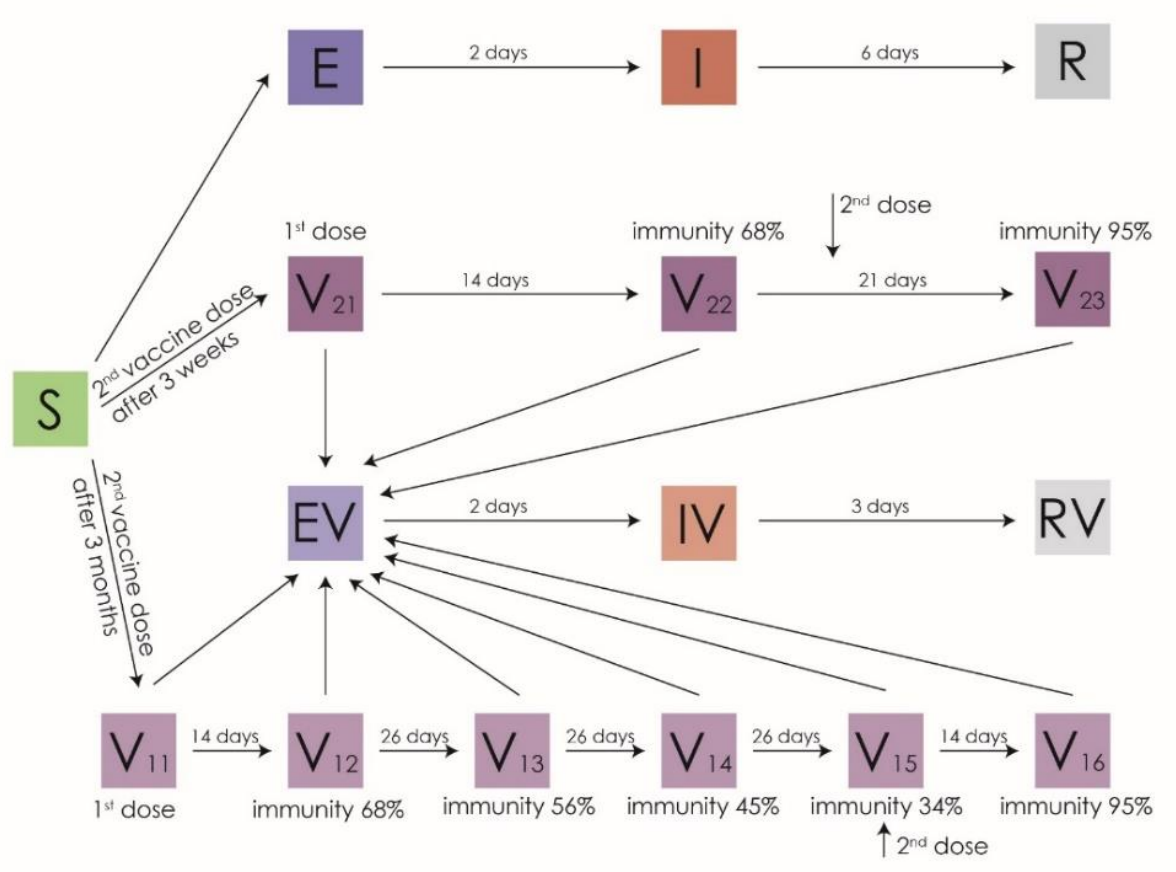

Figure 6: Schematic representation of the S(V)EIR epidemic model for the worst-case scenario regarding immunity waning.

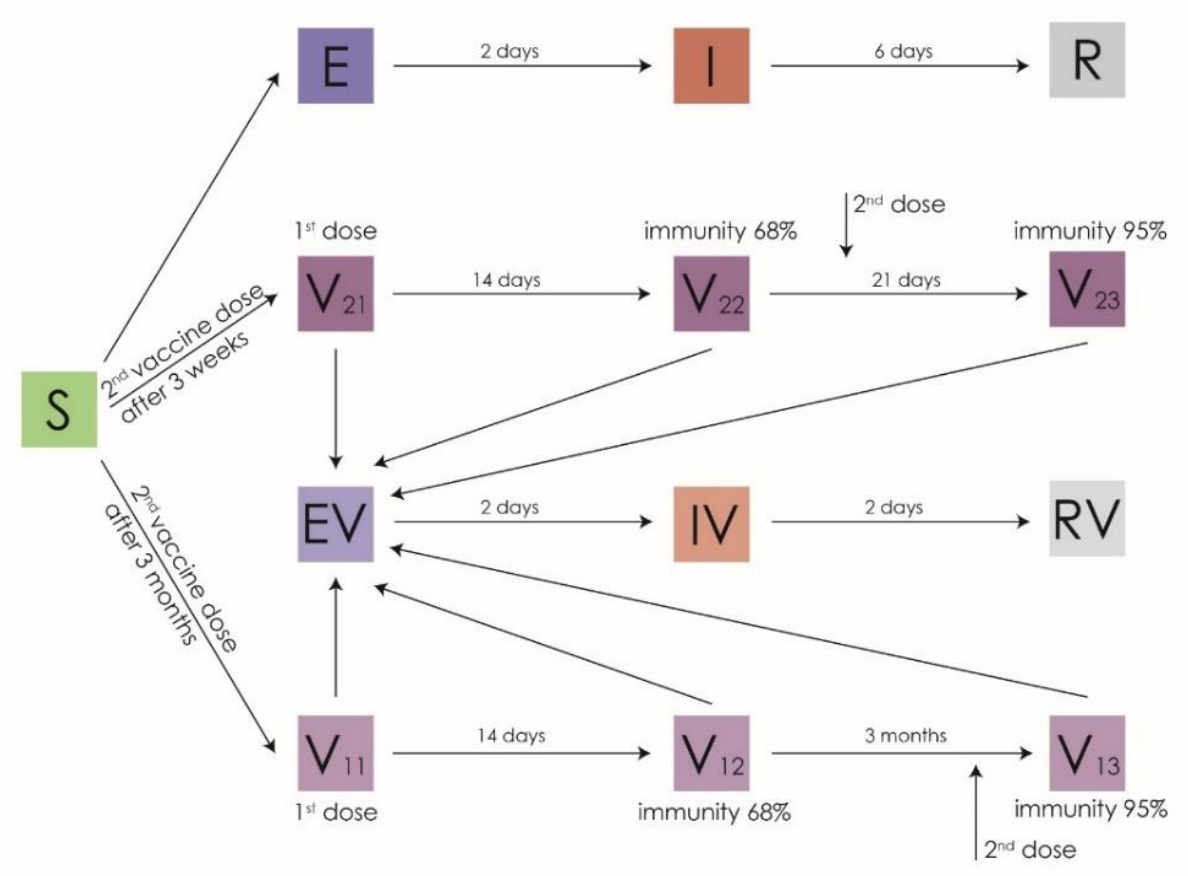

Figure 7: Schematic representation of the S(V)EIR epidemic model for the optimistic scenario regarding immunity waning. 


\section{Appendix $B$}

\subsection{Model assumptions}

\begin{tabular}{|c|c|c|}
\hline Parameters & Value & $\begin{array}{l}\text { Comments- } \\
\text { References }\end{array}$ \\
\hline$R_{0}$ & $\begin{array}{l}1.2 \\
1.4\end{array}$ & $\begin{array}{l}\text { Set to assess different } \\
\text { levels of transmission. } \\
\text { Ro is calculated as the } \\
\text { largest eigenvalue of } \\
\text { the next generation } \\
\text { matrix, using an } \\
\text { appropriate contact } \\
\text { matrix (see below). } \\
\text { We consider reduced } \\
\text { infection probability for } \\
\text { children by 48\% (Koh et } \\
\text { al., 2020). }\end{array}$ \\
\hline $\begin{array}{c}\text { Total } \\
\text { population }\end{array}$ & 10816287 & $\begin{array}{l}\text { Data from the Greek } \\
\text { Statistics Authority } \\
\text { (ELSTAT, 2021). }\end{array}$ \\
\hline $\begin{array}{l}\text { Population by } \\
\text { age goup }\end{array}$ & $\begin{aligned} 0-17: & 1908003(17.6 \%) \\
18-39: & 3200713(29.5 \%) \\
40-64: & 3539972(32.7 \%) \\
65+: & 2167599(20 \%)\end{aligned}$ & $\begin{array}{c}\text { Data from (ELSTAT, } \\
\text { 2021). } \\
\text { We assume that } \\
S=[N \text {-estimated number } \\
\text { of infected individuals], } \\
\text { with the estimated } \\
\text { number of infected } \\
\text { individuals } \sim 700000 .\end{array}$ \\
\hline $\begin{array}{l}\text { Exposed } \\
\text { period }\end{array}$ & $\begin{array}{l}2 \text { days for non-vaccinated and } \\
\text { vaccinated people }\end{array}$ & $\begin{array}{l}\text { Based on an average } \\
\text { incubation time of } \\
\text { approximately } 5 \text { days } \\
\text { (Li et al., 2020a, Lauer } \\
\text { et al., 2020) and } \\
\text { assuming that } \\
\text { infectiousness starts } \\
\text { approximately } 2 \text { days } \\
\text { prior to the occurrence } \\
\text { of symptoms (He et al., } \\
\text { 2020, Ganyani et al., } \\
\text { 2020, Li et al., 2020b). }\end{array}$ \\
\hline $\begin{array}{l}\text { Duration of } \\
\text { infectious } \\
\text { period for } \\
\text { non- } \\
\text { vaccinated } \\
\text { people }\end{array}$ & 6 days & $\begin{array}{c}\text { Serial interval of } \\
\text { approximately } 6 \text { days. } \\
\text { (Cereda et al.,2020; Bi } \\
\text { et al., 2020; Lavezzo et } \\
\text { al., 2020). }\end{array}$ \\
\hline $\begin{array}{l}\text { Duration of } \\
\text { infectious } \\
\text { period for } \\
\text { vaccinated } \\
\text { persons }\end{array}$ & $\begin{array}{c}3 \text { days (worst case scenario) } \\
2 \text { days (baseline scenario and } \\
\text { optimistic scenario, regarding vaccine } \\
\text { efficiency) }\end{array}$ & $\begin{array}{c}\text { Assuming, that } \\
\text { vaccinations decrease } \\
\text { the infectious period to } \\
\text { one third (baseline } \\
\text { scenario and optimistic }\end{array}$ \\
\hline
\end{tabular}


medRxiv preprint doi: https://doi.org/10.1101/2021.05.19.21257486; this version posted May 21, 2021. The copyright holder for this preprint (which was not certified by peer review) is the author/funder, who has granted medRxiv a license to display the preprint in perpetuity.

It is made available under a CC-BY-ND 4.0 International license .

\begin{tabular}{|c|c|c|}
\hline & & $\begin{array}{c}\text { scenario regarding } \\
\text { vaccine efficiency) and } \\
\text { to one half (worst case } \\
\text { scenario). }\end{array}$ \\
\hline $\begin{array}{l}\text { Age specific } \\
\text { infection } \\
\text { fatality ratios } \\
\text { (IFR) }\end{array}$ & $\begin{array}{c}0-17: 0.00003 \\
18-39: 0.00020 \\
40-64: 0.00500 \\
65+: 0.05400\end{array}$ & $(C D C, 2021)$ \\
\hline $\begin{array}{l}\text { Age specific } \\
\text { infection } \\
\text { fatality ratios } \\
\text { (IFR) for } \\
\text { vaccinated } \\
\text { people }\end{array}$ & $\begin{array}{c}0-17: 01.5 e-06 \\
18-39: 1.0 e-05 \\
40-64: 2.5 e-04 \\
65+: 2.7 e-03\end{array}$ & $\begin{array}{l}\text { We consider vaccinated } \\
\text { people are } 95 \% \text { less } \\
\text { probable of dying (Haas } \\
\text { et al., 2021). }\end{array}$ \\
\hline $\begin{array}{c}\text { Matrix of } \\
\text { contacts } \\
\text { between age } \\
\text { groups } \\
(0-17,18-39 \\
40-64,65+)\end{array}$ & $\begin{array}{c}\text { Mean number of contacts per day } \\
\text { between age groups }\end{array}$ & $\begin{array}{c}\text { Based on a social } \\
\text { contacts survey } \\
\text { assessing contacts in } \\
\text { Greece in the second } \\
\text { half of September } 2020 \\
\text { (unpublished data } \\
\text { collected using the } \\
\text { methodology described } \\
\text { in (Sypsa et al., 2021). }\end{array}$ \\
\hline \multicolumn{3}{|c|}{ Parameters related to vaccine efficacy and roll-out } \\
\hline $\begin{array}{l}\text { Vaccine } \\
\text { efficacy } \\
\text { following the } \\
1^{\text {st }} \text { dose and } \\
\text { before the } 2^{\text {nd }} \\
\text { dose }\end{array}$ & $68 \%$ & $\begin{array}{c}\text { 52.4\% }-92.6 \% \text { (Polack } \\
\text { et al., 2020; } \\
\text { Skowronski and De } \\
\text { Serres, 2021). } \\
\text { [Assuming also } \\
\text { reduction in the } \\
\text { probability of acquiring } \\
\text { infection]. This efficacy } \\
\text { is reached } 14 \text { days } \\
\text { post-vaccination. }\end{array}$ \\
\hline $\begin{array}{l}\text { Vaccine } \\
\text { efficacy after } \\
\text { the } 2^{\text {nd }} \text { dose }\end{array}$ & $95 \%$ & $\begin{array}{l}\text { Vaccine efficacy in } \\
\text { symptomatic infection } \\
\text { (Baden et al., 2021; } \\
\text { Polack et al., 2020). } \\
\text { [Assuming also } \\
\text { reduction in the } \\
\text { probability of acquiring } \\
\text { infection.] This efficacy } \\
\text { is reached } 14 \text { days } \\
\text { post-vaccination. }\end{array}$ \\
\hline $\begin{array}{c}\text { Available } \\
\text { doses over } \\
\text { time - normal } \\
\text { vaccine } \\
\text { availability } \\
(25 / 1 / 2021)\end{array}$ & $\begin{array}{l}\text { We assumed that the number of } \\
\text { doses increased during the first } \\
\text { quarter of } 2021 \text { from approximately } \\
81,000 \text { to } 2.5 \text { million and that it } \\
\text { ranged between } 4.0 \text { million to } 6.3 \\
\text { million per quarter after March } 2021 \text {. }\end{array}$ & \\
\hline
\end{tabular}


medRxiv preprint doi: https://doi.org/10.1101/2021.05.19.21257486; this version posted May 21, 2021. The copyright holder for this preprint (which was not certified by peer review) is the author/funder, who has granted medRxiv a license to display the preprint in perpetuity.

It is made available under a CC-BY-ND 4.0 International license .

\begin{tabular}{|c|c|c|}
\hline $\begin{array}{c}\text { Available } \\
\text { doses over } \\
\text { time - } \\
\text { reduced } \\
\text { Vaccine } \\
\text { Availability } \\
(25 / 1 / 2021)\end{array}$ & $\begin{array}{c}\text { We assumed that the number of } \\
\text { doses increased during the first } \\
\text { quarter of } 2021 \text { from approximately } \\
81,000 \text { to } 1 \text { million and that it ranged } \\
\text { between } 4.0 \text { million to } 6.3 \text { million per } \\
\text { quarter after March } 2021 \text {. }\end{array}$ & \\
\hline $\begin{array}{l}\text { Intention to } \\
\text { get vaccinated }\end{array}$ & $\begin{array}{c}\text { Approximately } 59 \%-79 \% \text { depending } \\
\text { on age }\end{array}$ & $\begin{array}{l}\text { Assessed in a sample of } \\
\text { 1,196 adults (Sypsa et } \\
\text { al, unpublished data } \\
\text { from a phone survey } \\
\text { implemented in } \\
\text { February 2021) }\end{array}$ \\
\hline
\end{tabular}

8 Appendix C

8.1.1 Baseline Scenario - Vaccine Availability - $R_{0}=1.2$

8.1.1.1 Cumulative Number of Deaths

8.1.1.1.1 $0 \%$ Vaccines allocated to ages 18-74

\begin{tabular}{|c|c|c|c|c|c|}
\hline $\begin{array}{l}\text { Cumulative } \\
\text { Deaths }\end{array}$ & $\begin{array}{l}\text { End of } \\
\text { March }\end{array}$ & End of June & $\begin{array}{l}\text { End of } \\
\text { August }\end{array}$ & $\begin{array}{l}\text { End of } \\
\text { October }\end{array}$ & $\begin{array}{c}\text { End of } \\
\text { December }\end{array}$ \\
\hline $0-17$ & $6(6-6)$ & $14(14-14)$ & $15(15-15)$ & $\begin{array}{c}16(16- \\
16)\end{array}$ & $17(17-17)$ \\
\hline $18-39$ & $\begin{array}{c}75(74- \\
75)\end{array}$ & $\begin{array}{c}143(143- \\
144)\end{array}$ & $\begin{array}{c}146(145- \\
146)\end{array}$ & $\begin{array}{c}146(146- \\
146)\end{array}$ & $\begin{array}{c}146(146- \\
146)\end{array}$ \\
\hline $40-64$ & $\begin{array}{c}1854 \\
(1846- \\
1863)\end{array}$ & $\begin{array}{c}3649 \\
(3646- \\
3652)\end{array}$ & $\begin{array}{c}3747 \\
(3745- \\
3749)\end{array}$ & $\begin{array}{c}3748 \\
(3746- \\
3750)\end{array}$ & $\begin{array}{c}3749 \\
(3747- \\
3751)\end{array}$ \\
\hline $65+$ & $\begin{array}{c}1897 \\
(1886- \\
1906)\end{array}$ & $\begin{array}{c}2384 \\
(2373- \\
2393)\end{array}$ & $\begin{array}{c}2425 \\
(2416- \\
2436)\end{array}$ & $\begin{array}{c}2461 \\
(2451- \\
2471)\end{array}$ & $\begin{array}{c}2495 \\
(2485- \\
2505)\end{array}$ \\
\hline $\begin{array}{l}\text { Total } \\
\text { deaths }\end{array}$ & $\begin{array}{c}3832 \\
(3812- \\
3850)\end{array}$ & $\begin{array}{c}6190 \\
(6176- \\
6203)\end{array}$ & $\begin{array}{c}6333 \\
(6321- \\
6346)\end{array}$ & $\begin{array}{c}6371 \\
(6359- \\
6383)\end{array}$ & $\begin{array}{c}6407 \\
(6395- \\
6419)\end{array}$ \\
\hline $\begin{array}{l}\text { Total life } \\
\text { years lost }\end{array}$ & $\begin{array}{l}73352.5 \\
(72982- \\
73685.5)\end{array}$ & $\begin{array}{c}134837.5 \\
(134670.5- \\
135044)\end{array}$ & $\begin{array}{l}138298.5 \\
(138122- \\
138435.5)\end{array}$ & $\begin{array}{c}138654 \\
(138524- \\
138784)\end{array}$ & $\begin{array}{c}138995.5 \\
(138865.5- \\
139125.5)\end{array}$ \\
\hline
\end{tabular}


medRxiv preprint doi: https://doi.org/10.1101/2021.05.19.21257486; this version posted May 21, 2021. The copyright holder for this preprint (which was not certified by peer review) is the author/funder, who has granted medRxiv a license to display the preprint in perpetuity.

It is made available under a CC-BY-ND 4.0 International license .

\subsection{0\% Vaccines allocated to ages $18-74$}

\begin{tabular}{|c|c|c|c|c|c|}
\hline $\begin{array}{c}\text { Cumulative } \\
\text { deaths }\end{array}$ & $\begin{array}{l}\text { End of } \\
\text { March }\end{array}$ & End of June & $\begin{array}{l}\text { End of } \\
\text { August }\end{array}$ & $\begin{array}{l}\text { End of } \\
\text { October }\end{array}$ & $\begin{array}{l}\text { End of } \\
\text { December }\end{array}$ \\
\hline $0-17$ & $6(6-6)$ & $14(14-14)$ & $\begin{array}{c}15(15- \\
15)\end{array}$ & $16(16-16)$ & $17(17-17)$ \\
\hline $18-39$ & $\begin{array}{c}75(74- \\
75)\end{array}$ & $\begin{array}{c}139(139- \\
139)\end{array}$ & $\begin{array}{c}141(141- \\
141)\end{array}$ & $\begin{array}{c}141(141- \\
141)\end{array}$ & $\begin{array}{c}141(141- \\
141)\end{array}$ \\
\hline $40-64$ & $\begin{array}{c}1852 \\
(1844- \\
1859)\end{array}$ & $\begin{array}{c}3550 \\
(3547- \\
3552)\end{array}$ & $\begin{array}{c}3632 \\
(3630- \\
3634)\end{array}$ & $\begin{array}{c}3634 \\
(3631- \\
3635)\end{array}$ & $\begin{array}{c}3635 \\
(3632- \\
3636)\end{array}$ \\
\hline $65+$ & $\begin{array}{c}1910 \\
(1900- \\
1919)\end{array}$ & $\begin{array}{c}2498 \\
(2488- \\
2506)\end{array}$ & $\begin{array}{c}2542 \\
(2533- \\
2551)\end{array}$ & $\begin{array}{c}2580 \\
(2571- \\
2589)\end{array}$ & $\begin{array}{c}2617 \\
(2609- \\
2626)\end{array}$ \\
\hline Total deaths & $\begin{array}{c}3843 \\
(3824- \\
3859)\end{array}$ & $\begin{array}{c}6201 \\
(6188- \\
6211)\end{array}$ & $\begin{array}{c}6330 \\
(6319- \\
6341)\end{array}$ & $\begin{array}{c}6371 \\
(6359- \\
6381)\end{array}$ & $\begin{array}{c}6410 \\
(6399- \\
6420)\end{array}$ \\
\hline $\begin{array}{l}\text { Total life } \\
\text { years lost }\end{array}$ & $\begin{array}{l}73383.5 \\
(73020- \\
73656.5)\end{array}$ & $\begin{array}{c}132451.5 \\
(132291.5- \\
132567.5)\end{array}$ & $\begin{array}{c}135400 \\
(135277- \\
135523)\end{array}$ & $\begin{array}{c}135799.5 \\
(135646.5- \\
135892.5)\end{array}$ & $\begin{array}{c}136162 \\
(136016- \\
136255)\end{array}$ \\
\hline
\end{tabular}

\subsection{0\% Vaccines allocated to ages $18-74$}

\begin{tabular}{|c|c|c|c|c|c|}
\hline $\begin{array}{c}\text { Cumulative } \\
\text { deaths }\end{array}$ & $\begin{array}{c}\text { End of } \\
\text { March }\end{array}$ & $\begin{array}{c}\text { End of } \\
\text { June }\end{array}$ & $\begin{array}{c}\text { End of } \\
\text { August }\end{array}$ & $\begin{array}{c}\text { End of } \\
\text { October }\end{array}$ & $\begin{array}{c}\text { End of } \\
\text { December }\end{array}$ \\
\hline $0-17$ & $6(6-6)$ & $13(13-13)$ & $15(15-15)$ & $\begin{array}{c}16(16- \\
16)\end{array}$ & $17(17-17)$ \\
\hline $18-39$ & $74(74-$ & $131(131-$ & $132(132-$ & $132(132-$ & $132(132-$ \\
$132)$ & $132)$ & $132)$ \\
\hline $40-64$ & 1847 & 3366 & 3419 & 3422 & 3423 \\
& $(1838-$ & $(3363-$ & $(3417-$ & $(3419-$ & $(3420-$ \\
& $1853)$ & $3369)$ & $3422)$ & $3424)$ & $3425)$ \\
\hline $65+$ & 1928 & 2723 & 2772 & 2816 & 2858 \\
& $(1919-$ & $(2713-$ & $(2762-$ & $(2806-$ & $(2848-$ \\
& $1941)$ & $2735)$ & $2784)$ & $2827)$ & $2869)$ \\
\hline Total deaths & 3855 & 6233 & 6338 & 6386 & 6430 \\
& $(3837-$ & $(6220-$ & $(6326-$ & $(6373-$ & $(6417-$ \\
& $3875)$ & $6249)$ & $6353)$ & $6399)$ & $6443)$ \\
\hline Total life & 73306 & 128005 & 130138.5 & 130610 & 131007.5 \\
years lost & $(72973-$ & $(127845-$ & $(130008.5-$ & $(130450-$ & $(130847.5-$ \\
& $73630.5)$ & $128232.5)$ & $130312.5)$ & $130747)$ & $131144.5)$ \\
\hline
\end{tabular}


medRxiv preprint doi: https://doi.org/10.1101/2021.05.19.21257486; this version posted May 21, 2021. The copyright holder for this preprint (which was not certified by peer review) is the author/funder, who has granted medRxiv a license to display the preprint in perpetuity.

It is made available under a CC-BY-ND 4.0 International license .

\subsection{0\% Vaccines allocated to ages $18-74$}

\begin{tabular}{|c|c|c|c|c|c|}
\hline $\begin{array}{c}\text { Cumulative } \\
\text { deaths }\end{array}$ & $\begin{array}{c}\text { End of } \\
\text { March }\end{array}$ & $\begin{array}{c}\text { End of } \\
\text { June }\end{array}$ & $\begin{array}{c}\text { End of } \\
\text { August }\end{array}$ & $\begin{array}{c}\text { End of } \\
\text { October }\end{array}$ & $\begin{array}{c}\text { End of } \\
\text { December }\end{array}$ \\
\hline $0-17$ & $6(6-6)$ & $13(13-13)$ & $15(15-15)$ & $\begin{array}{c}16(16- \\
16)\end{array}$ & $17(17-17)$ \\
\hline $18-39$ & $75(74-$ & $\begin{array}{c}129(129- \\
130)\end{array}$ & $\begin{array}{c}130(130- \\
130)\end{array}$ & $\begin{array}{c}130(130- \\
130)\end{array}$ & $\begin{array}{c}130(130- \\
130)\end{array}$ \\
\hline $40-64$ & 1854 & 3304 & 3311 & 3313 & 3314 \\
& $(1846-$ & $(3300-$ & $(3307-$ & $(3310-$ & $(3311-$ \\
& $1862)$ & $3309)$ & $3316)$ & $3319)$ & $3319)$ \\
\hline $65+$ & 1881 & 2278 & 2312 & 2340 & 2367 \\
& $(1870-$ & $(2268-$ & $(2302-$ & $(2330-$ & $(2357-$ \\
& $1889)$ & $2286)$ & $2320)$ & $2348)$ & $2375)$ \\
\hline Total deaths & 3816 & 5724 & 5768 & 5799 & 5828 \\
& $(3796-$ & $(5710-$ & $(5754-$ & $(5786-$ & $(5815-$ \\
& $3832)$ & $5738)$ & $5781)$ & $5813)$ & $5841)$ \\
\hline Total life & 73240.5 & 122923 & 123571.5 & 123901 & 124193.5 \\
years lost & $(72870-$ & $(122733-$ & $(123381.5-$ & $(123741-$ & $(124033.5-$ \\
& $73536.5)$ & $123182.5)$ & $123777.5)$ & $124137)$ & $124399.5)$ \\
\hline
\end{tabular}

\subsubsection{Cumulative Number of Infections}

8.1.1.2.1 $0 \%$ Vaccines allocated to ages 18-74

\begin{tabular}{|c|c|c|c|c|c|}
\hline $\begin{array}{c}\text { Cumulative } \\
\text { infections }\end{array}$ & $\begin{array}{c}\text { End of } \\
\text { March }\end{array}$ & $\begin{array}{c}\text { End of } \\
\text { June }\end{array}$ & $\begin{array}{c}\text { End of } \\
\text { August }\end{array}$ & $\begin{array}{c}\text { End of } \\
\text { October }\end{array}$ & $\begin{array}{c}\text { End of } \\
\text { December }\end{array}$ \\
\hline $0-17$ & 205692 & 407403 & 449126 & 483022 & 514726 \\
& $(201056-$ & $(395412-$ & $(434390-$ & $(465868-$ & $(495223-$ \\
& $210308)$ & $419507)$ & $464064)$ & $500426)$ & $534530)$ \\
\hline $18-39$ & 355723 & 657034 & 675324 & 678502 & 681604 \\
& $(349647-$ & $(642333-$ & $(658976-$ & $(661464-$ & $(663874-$ \\
& $361850)$ & $671954)$ & $691931)$ & $695861)$ & $699700)$ \\
\hline $40-64$ & 354386 & 668880 & 695936 & 699982 & 703266 \\
& $(348331-$ & $(654066-$ & $(679082-$ & $(682338-$ & $(684908-$ \\
& $360467)$ & $683859)$ & $713033)$ & $717904)$ & $721941)$ \\
\hline $65+$ & 42180 & 57708 & 59220 & 60525 & 61809 \\
& $(40320-$ & $(54237-$ & $(55278-$ & $(56142-$ & $(56997-$ \\
& $44094)$ & $61357)$ & $63394)$ & $65195)$ & $66971)$ \\
\hline
\end{tabular}


medRxiv preprint doi: https://doi.org/10.1101/2021.05.19.21257486; this version posted May 21, 2021. The copyright holder for this preprint (which was not certified by peer review) is the author/funder, who has granted medRxiv a license to display the preprint in perpetuity.

It is made available under a CC-BY-ND 4.0 International license .

8.1.1.2.2 20\% Vaccines allocated to ages $18-74$

\begin{tabular}{|c|c|c|c|c|c|}
\hline $\begin{array}{c}\text { Cumulative } \\
\text { infections }\end{array}$ & $\begin{array}{c}\text { End of } \\
\text { March }\end{array}$ & $\begin{array}{c}\text { End of } \\
\text { June }\end{array}$ & $\begin{array}{c}\text { End of } \\
\text { August }\end{array}$ & $\begin{array}{c}\text { End of } \\
\text { October }\end{array}$ & $\begin{array}{c}\text { End of } \\
\text { December }\end{array}$ \\
\hline $0-17$ & 205563 & 403485 & 445046 & 479322 & 511262 \\
& $(201024-$ & $(391605-$ & $(430414-$ & $(462237-$ & $(491857-$ \\
& $210191)$ & $415485)$ & $459859)$ & $496643)$ & $531012)$ \\
\hline $18-39$ & 355280 & 643554 & 662802 & 668244 & 671562 \\
& $(349268-$ & $(628986-$ & $(646528-$ & $(651052-$ & $(653659-$ \\
& $361332)$ & $658220)$ & $679252)$ & $685670)$ & $689750)$ \\
\hline $40-64$ & 353940 & 655699 & 682914 & 689238 & 693104 \\
& $(347968-$ & $(641042-$ & $(666185-$ & $(671522-$ & $(674617-$ \\
& $360029)$ & $670620)$ & $699958)$ & $707328)$ & $712012)$ \\
\hline $65+$ & 42170 & 58765 & 60310 & 61671 & 63013 \\
& $(40289-$ & $(55217-$ & $(56284-$ & $(57194-$ & $(58098-$ \\
& $44097)$ & $62461)$ & $64541)$ & $66410)$ & $68248)$ \\
\hline
\end{tabular}

8.1.1.2.3 50\% Vaccines allocated to ages $18-74$

\begin{tabular}{|c|c|c|c|c|c|}
\hline $\begin{array}{c}\text { Cumulative } \\
\text { infections }\end{array}$ & $\begin{array}{c}\text { End of } \\
\text { March }\end{array}$ & $\begin{array}{c}\text { End of } \\
\text { June }\end{array}$ & $\begin{array}{c}\text { End of } \\
\text { August }\end{array}$ & $\begin{array}{c}\text { End of } \\
\text { October }\end{array}$ & $\begin{array}{c}\text { End of } \\
\text { December }\end{array}$ \\
\hline $0-17$ & 205382 & 396362 & 437560 & 472510 & 504882 \\
& $(200846-$ & $(384695-$ & $(423185-$ & $(455670-$ & $(485694-$ \\
& $210114)$ & $408329)$ & $452361)$ & $489830)$ & $524631)$ \\
\hline $18-39$ & 354592 & 618118 & 638982 & 646856 & 650152 \\
& $(348511-$ & $(603982-$ & $(623014-$ & $(629797-$ & $(632378-$ \\
& $360648)$ & $632366)$ & $655121)$ & $664156)$ & $668213)$ \\
\hline $40-64$ & 353262 & 630735 & 658194 & 667522 & 671722 \\
& $(347216-$ & $(616477-$ & $(641843-$ & $(649974-$ & $(653378-$ \\
& $359440)$ & $645284)$ & $674894)$ & $685486)$ & $690546)$ \\
\hline $65+$ & 42128 & 60744 & 62360 & 63826 & 65248 \\
& $(40257-$ & $(57067-$ & $(58188-$ & $(59184-$ & $(60157-$ \\
& $44041)$ & $64557)$ & $66723)$ & $68701)$ & $70642)$ \\
\hline
\end{tabular}

8.1.1.2.4 100\% Vaccines allocated to ages $18-74$

\begin{tabular}{|c|c|c|c|c|c|}
\hline $\begin{array}{c}\text { Cumulative } \\
\text { infections }\end{array}$ & $\begin{array}{c}\text { End of } \\
\text { March }\end{array}$ & $\begin{array}{c}\text { End of } \\
\text { June }\end{array}$ & $\begin{array}{c}\text { End of } \\
\text { August }\end{array}$ & $\begin{array}{c}\text { End of } \\
\text { October }\end{array}$ & $\begin{array}{c}\text { End of } \\
\text { December }\end{array}$ \\
\hline $0-17$ & 205698 & 394808 & 434849 & 470048 & 502502 \\
& $(201113-$ & $(383203-$ & $(420571-$ & $(453294-$ & $(483371-$ \\
& $210283)$ & $406569)$ & $449360)$ & $487112)$ & $521985)$ \\
\hline $18-39$ & 355640 & 611915 & 638422 & 645310 & 648467 \\
& $(349658-$ & $(598340-$ & $(622750-$ & $(628653-$ & $(631115-$ \\
& $361635)$ & $625688)$ & $654357)$ & $662313)$ & $666220)$ \\
\hline $40-64$ & 354362 & 623402 & 651674 & 661004 & 664376 \\
& $(348317-$ & $(609535-$ & $(635668-$ & $(643853-$ & $(646514-$ \\
& $360332)$ & $637325)$ & $667804)$ & $678331)$ & $682482)$ \\
\hline $65+$ & 42111 & 59390 & 61865 & 63053 & 64212 \\
& $(40235-$ & $(55683-$ & $(57562-$ & $(58343-$ & $(59091-$ \\
& $44022)$ & $63234)$ & $66355)$ & $68022)$ & $69658)$ \\
\hline
\end{tabular}

